\title{
Isolation of total RNA from hard bamboo tissue rich in polyphenols and polysaccharides for gene expression studies
}

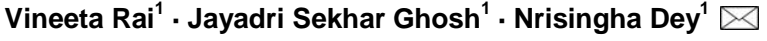 \\ 1 Institute of Life Sciences, Nalco Square, Bhubaneswar-751 023, India \\ $\triangle$ Corresponding author: dey@ils.res.in \\ Received December 15, 2009 / Accepted July 12, 2010 \\ Published online: September 15, 2010 \\ (c) 2010 by Pontificia Universidad Católica de Valparaíso, Chile
}

\begin{abstract}
RNA isolation from hard and woody internodal bamboo (Bambusa balcooa) tissue is very difficult due to the presence of secondary metabolites, polysaccharides, and polyphenolics. These compounds often co-precipitate with isolated RNA and hinder downstream applications. We have developed an efficient, cost effective and reproducible RNA isolation method from hard tissue of bamboo internode. This protocol includes an additional organic solvent refinement steps to remove endogenous phenolic compounds and acidic phenol $(\mathrm{pH} 4.2)$ to critically stabilize RNA in extraction buffer. In addition to these, two $2 \mathrm{M}$ Lithium chloride washing steps were introduced to eliminate DNA and polysaccharides contamination. The RNA isolated from the present protocol was found to be superior, when compared to total RNA extracted by other available protocols. The $A_{260} / A_{280}$ absorption ratio of the isolated RNA was found ranging between 1.89-1.97. The integrity of $28 \mathrm{~S}$ and $18 \mathrm{~S}$ rRNA was highly satisfactory when analyzed in agarose denaturing gel. RNA was further used for RT PCR, northern hybridization, cDNA library and subtractive hybridization without any further refinement.
\end{abstract}

Keywords: acid phenol, Bambusa balcooa, fiber specific genes, internode, RNA extraction

\section{INTRODUCTION}

Bamboos are distinct and fascinating plants, with a wide range of values and uses. It may replace wood in many industrial and domestic applications and thereby contribute to the saving and restoration of the world's forests. In tropical countries, bamboo plays an important role in economy development and civilization. Beside these, bamboos are also enriched with high-quality fiber and today bamboo is considered as one of the most important alternative resources of fibers. Therefore the characterizations of fiber-specific genes are of great importance for elucidating the underlying mechanism of fiber cell elongation and maturation (Arpat et al. 2004; Gou 
et al. 2007; Luo et al. 2007) and the knowledge may become worthy for translational research. Fiber specific genes could be identified through cDNA subtraction approaches using RNA isolated from different internodes of bamboo (Bambusa balcooa), as the differential expressions of fiber related genes are bamboo's developmental stage specific but till now no suitable protocol for RNA isolation from bamboo internodal tissue was reported.

Isolation of good quality RNA from hard internodal bamboo tissues is troublesome and really challenging because it contains high percentage of dead tissue, secondary metabolites like cellulose, polysaccharides and phenolic compounds, invariably these compounds inhibit extraction of good quality RNA (Loomis, 1974). RNA isolation from soft bamboo tissues like shoot and leaf has been reported earlier (Matsui et al. 2004;

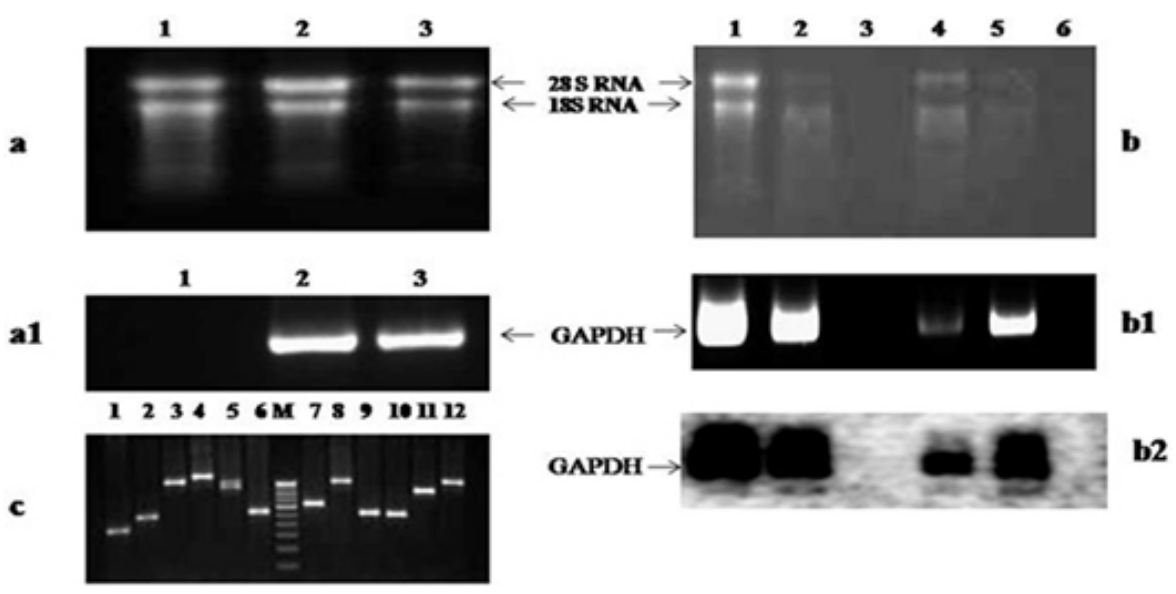

Fig. 1 Qualitative and quantitative estimation of RNA isolated by present and others methods. (a) Total RNA isolated using present protocol from different internodal tissues of Bambusa balcooa. RNA (approximately $1.0 \mu \mathrm{g}$ each) from $2^{\text {nd }} ; 5^{\text {th }}$ and $10^{\text {th }}$ in Lanes 1,2 and 3 respectively were electrophorosed on $1.2 \%(\mathrm{w} / \mathrm{v})$ formaldehyde denaturing agarose gel. The $28 \mathrm{~S}$ and 18S rRNA bands were indicated by arrows. (a1) Electrophoresis of PCR amplified GAPDH gene on 1\% agarose gel using isolated RNA by present protocol as template (Lane 1); cDNA prepared from isolated RNA as template (Lane 2) and genomic DNA of bamboo as template (Lane 3). (b) Comparison of total RNA isolated from $5^{\text {th }}$ internode of Bambusa balcooa by different method on $1.2 \%(\mathrm{w} / \mathrm{v})$ formaldehyde denaturing agarose gel. Lanes 1 , using present method; 2, using method of Chan et al. 2007; 3, using method of Vasanthaiah et al. 2008; 4, using method of Chiu et al. 2006; 5, by Trizol Reagent (Invitrogene, cat.\# 10296010); 6, using method of Weng et al. 2009. (b1) RT-PCR band (GADPH, $476 \mathrm{bp}$ ) obtained using RNA isolated from $5^{\text {th }}$ internode by different protocols. Lanes 1 , using present method; 2 , using method of Chan et al. 2007; 3, using method of Vasanthaiah et al. 2008; 4, using method of Chiu et al. 2006; 5, from Trizol Reagent; and 6, using method of Weng et al. 2009. (b2) The GADPH gene was detected on northern blot using total RNA isolated from $5^{\text {th }}$ internodal bamboo tissue by different methods. Lanes 1, using present method; 2, using method of Chan et al. 2007; 3, using method of Vasanthaiah et al. 2008; 4, using method of Chiu et al. 2006; 5, by Trizol reagent; and 6 , using method of Weng et al. 2009. (c) A representation of subtraction cDNA library constructed using RNA from $2^{\text {nd }}$ and $10^{\text {th }}$ internode of bamboo. PCR amplifications of inserts obtained from different subtractive cDNA clones using SP6 and T7 primers. PCR products were run with a 100 bp marker (Bangalore Genei, cat.\#105993) in a 1.0\% agarose gel. 
Chiu et al. 2006; Weng et al. 2009), also there were few protocols describing RNA isolation from woody tissue (Chang et al. 1993; Chan et al. 2007; Vasanthaiah et al. 2008) but all these methods were found to be unsuitable for extracting high quality total RNA from bamboo's hard internodes.

In addition to these there are several commercial kits available for RNA isolation. These kits also failed to give satisfactory results. To overcome these failures a new RNA isolation method from internode tissue of bamboo (Bambusa balcooa), an important bamboo species known for its high quality fiber (Bhatt et al. 2003; Bhattacharya et al. 2010) is described in this study.

\section{MATERIALS AND METHODS}

Samples of fully developed bamboo (Bambusa balcooa) aging around 10-15 years were collected from Regional Plant Resource Centre (RPRC) Bhubaneswar, Orissa, India. The internodal tissues $\left(2^{\text {nd }}, 5^{\text {th }}\right.$ and $10^{\text {th }}$ from apex), leaves and rhizome were collected and transfer immediately to dry ice. On arrival to the laboratory they were stored in $-80^{\circ} \mathrm{C}$ until extraction.

\section{Solutions required}

- Extraction Buffer: $0.25 \mathrm{M} \mathrm{NaCl}, 0.05 \mathrm{M}$ Tris- $\mathrm{HCl}(\mathrm{pH} 7.5), 0.02 \mathrm{M}$ EDTA, 1\% (w/v) SDS, 2\% 2-mercaptoethanol.

- DEPC-treated water (0.1\%).

- $2 \mathrm{M}$ and $8 \mathrm{M} \mathrm{LiCl}$.

- $70 \%$ and absolute ethanol.

- 3 M NaOAc; pH 5.2.

$-10 \%$ SDS.

- Phenol (pH 4.2):Chloroform:isoamylalcohol (25:24:1; V/V).

- Chloroform:isoamylalcohol (24:1; V/V).

$-5 \mathrm{M} \mathrm{NaCl}$.

- 0.5 M EDTA; pH 8.0.

- 1 M Tris- $\mathrm{HCl} ; \mathrm{pH} 7.5$.

All aqueous solutions, except Tris- $\mathrm{HCl}$ were treated with DEPC and autoclaved (Sambrook et al. 2001). Tris- $\mathrm{HCl}$ was prepared using DEPC treated autoclaved water. 
Rai et al.

\section{RNA extraction protocol}

1. Prepare $15 \mathrm{ml}$ of extraction buffer in $50 \mathrm{ml}$ tube for a single extraction. Use $5-7 \mathrm{ml}$ extraction buffer for $1 \mathrm{gm}$ sample.

2. Grind $1.0 \mathrm{gm}$ frozen bamboo sample (internodes, leaves and rhizome) to fine powder with a mortar and pestle in liquid nitrogen.

3. Transfer $1.0 \mathrm{gm}$ of ground sample to a tube containing the extraction buffer. Incubate at RT for $30 \mathrm{~min}$, vortex in every $5 \mathrm{~min}$.

4. Add choloroform: isoamyl alcohol (24:1) in equal volume. Vortex for 5 min.

5. Centrifuge at $11000-12000 \mathrm{~g}$ for $10 \mathrm{~min}$ at room temperature and transfer the supernatant to a new $50 \mathrm{ml}$ tube.

6. Add equal volume of phenol:chloroform:isoamyl alcohol (25:24:1) and vortex for 5 $\min$.

7. Centrifuge at $11000-12000 \mathrm{~g}$ for $10 \mathrm{~min}$ at RT and transfer supernatant to a new 50 $\mathrm{ml}$ tube. Repeat this step until clean interface observed.

8. Add choloroform:isoamyl alcohol (24:1) in equal volume, vortex for $5 \mathrm{~min}$.

9. Centrifuge at $11000-12000 \mathrm{~g}$ for $10 \mathrm{~min}$ at RT.

10. Transfer the supernatant to a new $50 \mathrm{ml}$ tube, add one tenth volume of $3 \mathrm{M}$ $\mathrm{NaOAc}(\mathrm{pH} \mathrm{5.2)}$ and 2.5 volume of chilled absolute ethanol, mix well, and incubate at $4^{\circ} \mathrm{C}$ for $2-3 \mathrm{hrs}$.

11. Recover the nucleic acids by centrifugation at $12,000 \mathrm{~g}$ for $30 \mathrm{~min}$ at $4^{\circ} \mathrm{C}$.

12. Discard the supernatant and resuspend the pellet in $750 \mu$ of RNase free water, transfer it into a centrifuge tube and add $250 \mu \mathrm{l}$ of $8 \mathrm{M} \mathrm{LiCl}$ (so that the final concentration of $\mathrm{LiCl}$ becomes $2 \mathrm{M}$ ). Incubate these tubes at $4^{\circ} \mathrm{C}$ for overnight.

13. Centrifuges at $17000 \mathrm{~g}$ for $30 \mathrm{~min}$ at $4^{\circ} \mathrm{C}$.

14. Wash the pellet twice with $2 \mathrm{M} \mathrm{LiCl}$ by centrifugation at $17000 \mathrm{~g}$ for $10 \mathrm{~min}$ at $4^{\circ} \mathrm{C}$.

15. Wash the pellet with $70 \%(\mathrm{v} / \mathrm{v})$ ethanol by centrifugation at $17000 \mathrm{~g}$ for $5 \mathrm{~min}$ at $4^{\circ} \mathrm{C}$.

16. Wash the pellet with absolute ethanol by centrifugation at $17000 \mathrm{~g}$ for $2 \mathrm{~min}$ at $4^{\circ} \mathrm{C}$.

17. Air-dry the pellet for 5-10 min. 
18. Add $50 \mu$ I DEPC-treated water to suspend the pellet.

\section{Estimation of RNA quality}

The isolated RNA was quantified by OD measurement in spectrophotometer (Cecil; CE2501) with 100 times dilution. OD was taken at $230 \mathrm{~nm}, 260 \mathrm{~nm}$ and $280 \mathrm{~nm}$. In order to verify RNA integrity isolated RNA was subjected to $1.2 \%$ agarose formaldehyde denaturing gel electrophoresis. Gel was then stained with $\mathrm{EtBr}$ and visualized under UV light.

\section{Check for DNA contamination}

Presence of DNA contamination in isolated RNA was examined (Oñate-Sanchez and Vicente-Carbajosa 2008; Singh et al. 2009) cDNA synthesis was performed using first strand cDNA synthesis kit (Fermentas; Cat\# K1612) as per Kit's instruction followed by PCR amplification of GAPDH gene using gene specific primers. In negative control, reverse transcriptase was substituted by RNase-free water. In the positive control, genomic DNA isolated from bamboo was used in place of RNA.

\section{First strand cDNA synthesis and PCR}

Single stranded cDNA was prepared from $2.5 \mu \mathrm{g}$ total RNA using first strand cDNA synthesis kit (Fermentas; cat\#K1612), following the manufacturer's instructions. The synthesized cDNA was used for GAPDH (Glyceraldehyde 3-phosphate dehydrogenase) gene amplification using gene specific primers; forward primer (5' CAAGGTCATCCATGACAACTTTG 3') and reverse primer (5' GTCCACCACCCTGTTGCTGTAG 3'). PCR cycles were as follows; DNA denaturing at $94^{\circ} \mathrm{C}$ for $2 \mathrm{~min}$, followed by 25 cycles of $30 \mathrm{sec}$ at $94^{\circ} \mathrm{C}, 30 \mathrm{sec}$ at $58^{\circ} \mathrm{C}$ and $45 \mathrm{sec}$ at $72^{\circ} \mathrm{C}$ followed by an extension of $72^{\circ} \mathrm{C}$ for $5 \mathrm{~min}$. The amplified products were separated on a 1.0\% agarose gel and visualize after EtBr staining.

\section{Northern blot analysis}

Total RNA $(5 \mu \mathrm{g})$ isolated from bamboo $5^{\text {th }}$ internodal tissue using new protocol and other methods (Chiu et al. 2006; Chan et al. 2007; Trizol reagent; Vasanthaiah et al. 2008; Weng et al. 2009) were subjected to electrophoresis on a $1.2 \%$ agarose gel containing $0.66 \mathrm{M}$ formaldehyde, and then transferred to a IMMOBILON-NY+ membrane (Cat\# INYC00010; Millipore, Billerica, MA, USA) by capillary action in 10X

Table 1. RNA isolated using present protocol from $2^{\text {nd }}, 5^{\text {th }}$ and $10^{\text {th }}$ internodes of bamboo.

\begin{tabular}{lccccccc}
\hline $\begin{array}{l}\text { Different tissues } \\
\text { from B. balcooa }\end{array}$ & O.D.260 & O.D.280 & O.D.230 & $\mathbf{2 6 0 / 2 8 0}$ & $\mathbf{2 6 0 / 2 3 0}$ & $\begin{array}{c}\text { Conc. } \\
(\boldsymbol{\mu} \mathbf{g} / \boldsymbol{\mu L})\end{array}$ & $\begin{array}{c}\text { Yield } \\
(\boldsymbol{\mu} \mathbf{g} / \mathbf{g m})\end{array}$ \\
\hline $2^{\text {nd }}$ Internode & 0.528 & 0.276 & 0.262 & 1.91 & 2.01 & 2.112 & 84.48 \\
$5^{\text {th }}$ Internode & 0.584 & 0.296 & 0.307 & 1.97 & 1.90 & 2.336 & 93.44 \\
$10^{\text {th }}$ Internode & 0.496 & 0.262 & 0.236 & 1.89 & 2.10 & 1.984 & 79.36 \\
\hline
\end{tabular}


Rai et al.

SSC ( $1 \mathrm{X}$ of SSC is $0.15 \mathrm{M} \mathrm{NaCl}, 15 \mathrm{mM}$ Sodium citrate) overnight and immobilized by UV-cross-linking (Sambrook et al. 2001). Bamboo RNA isolated using different methods were specifically hybridized with $\mathrm{P}^{32}$ labelled GAPDH gene probe synthesized using random primer labeling kit (NEB; Cat\# N1500S), at $65^{\circ} \mathrm{C}$ overnight, then after successive washing, northern blot was developed and autoradiographed using Phosphor imager (FujiFilm).

\section{Subtraction cDNA library construction}

RNA samples were isolated from $2^{\text {nd }}$ and $10^{\text {th }}$ internode of bamboo (Bambusa balcooa) by this new approach were used for cDNA subtraction library construction following the instructions described in PCR select CDNA subtraction Kit (Clonetech; Cat\# 637401).

\section{RESULTS AND DISCUSSION}

Total RNA extracted from hard bamboo tissue $\left(2^{\text {nd }}, 5^{\text {th }}\right.$ and $10^{\text {th }}$ internodes $)$ using the new protocol discussed above produced two distinct rRNA bands ( $28 \mathrm{~S}$ and $18 \mathrm{~S}$ ) and showed no DNA contamination in agarose-formaldehyde denaturing gel; further $A_{260 / 280}$ and $A_{260 / 230}$ ratios were found ranging from 1.89-1.97 and $1.9-2.10$ respectively, indicating presence of no protein, salt and solvent as contaminants (Figure 1a, Table 1). No DNA contamination was detected in the isolated RNA sample. There was no PCR amplification of GAPDH gene when isolated RNA was used as template (Figure 1a1, Lane 1) while discrete GAPDH specific bands were obtained in cases when bamboo genomic DNA (Figure 1a1, Lane 2) and cDNA fragment isolated from RNA sample (Figure 1a1, Lane 3) were use as templates in PCR reactions. Moreover present protocol also yields quality RNA from bamboo leaves and rhizome (data not shown). RNA extracted using the current method was found to be superior when compared to RNA isolated by other methods (Figure $1 \mathrm{~b}$, Table 2) in terms of their purity, integrity, quantity and downstream applications. A discrete RT-PCR band of GAPDH (Glyceraldehyde 3-phosphate dehydrogenase) was obtained in case of RNA isolated from $5^{\text {th }}$ internodal tissues of Bambusa balcooa by the present protocol (Figure 1b1) as compared to very faint RT-PCR bands of GAPDH obtained from RNA isolated from $5^{\text {th }}$ internode by other methods. This data was again verified using northern blot analysis of total RNA. RNA $(5 \mu \mathrm{g})$ isolated from bamboo $5^{\text {th }}$ internodal tissue using present protocol and other methods were subjected to northern blot analysis. Distinct GAPDH-band was detected in case of RNA isolated by the present method while in other cases very faint bands were detected (Figure 1b2).

Table 2. RNA isolated from $5^{\text {th }}$ internode of $B$. balcooa using other protocols.

\begin{tabular}{cccccccc}
\hline METHOD & O.D.260 & O.D.280 & O.D.230 & $\mathbf{2 6 0 / 2 8 0}$ & $\mathbf{2 6 0 / 2 3 0}$ & $\begin{array}{c}\text { Conc. } \\
(\boldsymbol{\mu g} / \boldsymbol{\mu L})\end{array}$ & $\begin{array}{c}\text { Yield } \\
(\boldsymbol{\mu g} / \mathbf{g m})\end{array}$ \\
\hline $\begin{array}{c}\text { Chan et al. 2007 } \\
\text { Vasanthaiah et al. }\end{array}$ & 0.288 & 0.180 & 0.136 & 1.60 & 2.12 & 1.152 & 46.08 \\
$\quad$ 2008 & 0.028 & 0.022 & 0.016 & 1.27 & 1.75 & 0.112 & 4.48 \\
$\begin{array}{c}\text { Chiu et al. 2006 } \\
\text { Trizol reagent }\end{array}$ & 0.198 & 0.120 & 0.104 & 1.65 & 1.90 & 0.792 & 31.68 \\
Weng et al. 2009 & 0.054 & 0.038 & 0.034 & 1.79 & 2.0 & 0.272 & 10.88 \\
\hline
\end{tabular}


Intensities of northern bands were quantified using the software (Multi Gauge Ver. 2.2) attached to the Imaging system and the ratios were found 8.58:6.67:1:3.41:4.38:1.29 (Present method: Chiu et al. 2006; Chan et al. 2007; Vasanthaiah et al. 2008; Trizol Kit; Weng et al. 2009 respectively). RNA isolated by present acid phenol method was also used for construction of several subtractive cDNA libraries. One such library was constructed using RNA extracted from tissues of $2^{\text {nd }}$ and $10^{\text {th }}$ internode of bamboo (Bambusa balcooa) following the instructions described in PCR select cDNA subtraction kit (Clonetech; Cat\# 637401). This library showed a wide range of clones with insert size varying from $0.1 \mathrm{~kb}$ to $2.0 \mathrm{~kb}$ having percentage distribution of inserts as follows; between 0-0.5 Kb (55.6\%), 0.5-1.0 Kb (37.3\%), 1.0-1.5 Kb (5.06\%) and $1.5-2.0 \mathrm{~Kb}(2 \%)$ respectively (Figure 1c). All these results clearly indicate that the RNA isolation protocol described here has immense potential for extracting high quality RNA from hard bamboo internodes.

The present method is simple, fast, cost-effective and highly reproducible. There were several key points to be taken under consideration when formulating the present acid phenol method. The phenol used in the present protocol was acidic in nature $(\mathrm{pH} 4.0$ 5.5). RNA molecules are usually found stable in a pH range of 5.0 to 6.0 . High pH (>7.5) and presence of divalent cataions favored the hydrolysis of phosphodiester bonds present in RNA (Wiame et al. 2000). In the present method, EDTA was used to sequester bivalent cataions like $\mathrm{Mn}^{+2}$ or $\mathrm{Mg}^{+2}$. Acidic phenol and EDTA render more RNA stability by inhibiting degradation of RNA phosphodiester bonds in presence of bivalent cataions. One extra chloroform-isoamylalcohol purification step was included prior to phenol:chloroform:isoamylalcohol (25:24:1) step to remove endogenous phenolic compounds specifically followed by phenol:chloroform:isoamylalcohol $(25: 24: 1)$ step which confirmed more efficient removal of protein during RNA preparation. Guanidium isothiocyanate and polyvinyl pyrolidone widely used for plant RNA isolation. These reagents were not used in the present protocol as the lysates obtained were found to be contaminated with a significant extent of cellular polysachharide and proteoglycans. These contaminations are reported to prevent suspension of RNA after precipitation with alcohol and thus inhibiting further downstream processes (Groppe and Morse, 1993). Present acid phenol method thus avoids the use of guanidium isothiocyanate and polyvinyl pyrolidone guanidium isothiocyanate.

The present new method with its potential can thus be used successfully for deciphering the genome architecture of this golden plant, bamboo, using functional genomics approaches.

\section{ACKNOWLEDGMENTS}

Authors are grateful to the Director of Institute of Life Sciences.

Financial support: This work was supported by National Science and Technology Development Agency (NSTDA), Thailand and the project numbers are CO-B-22-2C-10-483 and CO-B-22-2C18-4801 including the Graduate School, Prince of Songkla University. 


\section{REFERENCES}

ARPAT, A. Bulak; WAUGH, Mark; SULLIVAN, John P.; GONZALES, Michael; FRISCH, David; MAIN, Dorrie; WOOD Todd; LESLIE, Anna; WING, Rod and WILKINS, Thea. Functional genomics of cell elongation in developing cotton fibres. Plant Molecular Biology, April 2004, vol. 54, no. 6, p. 911-929. [CrossRef]

BHATT, B.P.; SINGH, L.B.; SINGH, K. and SACHAN, M.S. Some commercial edible bamboo species of North East India: Production, indigenous uses, cost-benefit and management strategies. Bamboo Science and Culture, 2003, vol. 17, no. 1, p. 4-20.

BHATTACHARYA, Samik; GHOSH, Jayadri S.; SAHOO, Dipak; DEY, Nrisingha and PAL, Amita. Screening of superior fiber-quality-traits among wild accessions of Bambusa balcooa: efficient and non-invasive evaluation of fiber developmental stages. Annals of Forest Science, September 2010, vol. 67, no. 6, p. 611. [CrossRef]

CHAN, Kam-Lock; HO, Chai-Ling; NAMASIVAYAM, Parameswari and NAPIS, Suhaimi. A simple and rapid method for RNA isolation from plant tissues with high phenolic compounds and polysaccharides. Nature Protocol, 2007, vol. 184. [CrossRef]

CHANG, Shujun; PURYEAR, Jeff and CAIRNEY, John. A simple and efficient method for isolating RNA from pine trees. Plant Molecular Biology Reporter, June 1993, vol. 11, no. 2, p. 113-116. [CrossRef]

CHIU, Wen-Bin; LIN, Chiou-Hong; CHANG, Chun-Ju; HSIEH, Meng-Hsun and WANG, Ai-Yu. Molecular characterization and expression of four cDNAs encoding sucrose synthase from green bamboo Bambusa oldhamii. New Phytologist, March 2006, vol. 170, no. 1, p. 53-63. [CrossRef]

GOU, Jin-Ying; WANG, Ling-Jian; CHEN, Shuang-Ping; HU, Wen-Li and CHEN, Xiao-Ya. Gene expression and metabolite profiles of cotton fiber during cell elongation and secondary cell wall synthesis. Cell Research, 2007, vol. 17, no. 5, p. 422-434. [CrossRef]

GROPPE, J.C. and MORSE, D.E. Isolation of full-length RNA templates for reverse transcriptase from tissues rich in RNase and proteoglycans. Analytical Biochemistry, May 1993, vol. 210, no. 2, p. 337-343.[CrossRef]

LOOMIS, W.D. Overcoming problems of phenolics and quinones in the isolation of plant enzymes and organelles. Methods in Enzymology, 1974, vol. 31, p. 528-544. [CrossRef]

LUO, Ming; XIAO, Yuehua; LI, Xianbi; LU, Xiaofeng; DENG, Wei; LI, Demou; HOU, Lei; HU, Mingyu; LI, Yi and PEI, Yan. GhDET2, a steroid 5a-reductase, plays an important role in cotton fiber cell initiation and elongation. The Plant Journal, August 2007, vol. 51, no. 3, p. 419-430.[CrossRef]

MATSUI, Toshiyuki; BHOWMIK, Pankaj Kumar and YOKOZEKI, Kyosuke. A cDNA sequence encoding actin gene in moso bamboo shoot and its phylogenetic analysis. Asian Journal of Plant Sciences, 2004, vol. 3, no. 1, p. 128-131. [CrossRef]

OÑATE-SANCHEZ, Luis and VICENTE-CARBAJOSA, Jesús. DNA-free RNA isolation protocols for Arabidopsis thaliana, including seeds and siliques. BMC Research Notes, 2008, vol. 1 , no. 93. [CrossRef]

SAMBROOK, J.; FRITSCH, E.F. and MANIATIS, T. Molecular Cloning: A Laboratory Manual. Cold Spring Harbor, New York, Cold Spring Harbor Laboratory Press. 2001. $3^{\text {rd }}$ ed. ISBN 0-87969-576-3.

SINGH, Rajesh K.; MISHRA, Aparna; SANE, Vidhu-A. and PRAVENDRA, Nath. Isolation of high quality RNA from oil seeds of Jatropha curcas. Journal Plant Biochemistry and Biotechnology, June 2009, vol. 18, no. 1, p. 77-81.

VASANTHAIAH, Hemanth K.N.; KATAM, Ramesh and SHEIKH, Mehboob B. Efficient protocol for isolation of functional RNA from different grape tissue rich in polyphenols and polysaccharides for gene expression studies. Electronic Journal of Biotechnology, July 2008, vol. 11, no. 3. [CrossRef]

WENG, Chia-Jui; DENG, Jen-Ying; LIN, Da-Gin and JEANG, Chii-Ling. Cloning, Expression and characterization of UDP-Glucose pyrophosphorylase from shoots of Bambusa oldhamii. The Journal of Biochemistry, June 2009. [CrossRef]

WIAME, I.; REMY, S.; SWENNEN, R. and SAGI, L. Irreversible heat inactivation of DNase I without RNA degradation. Biotechniques, August 2000, vol. 29, no. 2, p. 252-256. 


\section{How to cite this article:}

RAI, V.; GHOSH, J.S. and DEY, N. Isolation of total RNA from hard bamboo tissue rich in polyphenols and polysaccharides for gene expression studies. Electronic Journal of Biotechnology, September 2010, vol. 13, no. 5. http://dx.doi.org/10.2225/vol13-issue5fulltext-17 